\title{
Social Economy and Social Business Supporting Policies for Sustainable Human Development in a Post-COVID-19 World
}

\author{
Muhammad Yunus ${ }^{1}$, Mario Biggeri ${ }^{2,3,4, *(D)}$ and Enrico Testi $^{3,4}$ (D) \\ 1 Yunus Centre, Dhaka 1216, Bangladesh; yunus@yunuscentre.org \\ 2 Department of Economics and Management, University of Florence, 50127 Florence, Italy \\ 3 Yunus Social Business Centre, University of Florence, 59100 Prato, Italy; enrico.testi@pin.unifi.it \\ 4 ARCO (Action Research for CO-Development), 59100 Prato, Italy \\ * Correspondence: mario.biggeri@unifi.it; Tel.: +39-055-2757561
}

check for

updates

Citation: Yunus, M.; Biggeri, M.; Testi, E. Social Economy and Social Business Supporting Policies for Sustainable Human Development in a Post-COVID-19 World. Sustainability 2021, 13, 12155. https://doi.org/ $10.3390 /$ su132112155

Academic Editors: Carlos

Lopez-Gutierrez, Ana

Fernandez-Laviada and Andrea Pérez

Received: 30 September 2021

Accepted: 31 October 2021

Published: 3 November 2021

Publisher's Note: MDPI stays neutral with regard to jurisdictional claims in published maps and institutional affiliations.

Copyright: (c) 2021 by the authors. Licensee MDPI, Basel, Switzerland. This article is an open access article distributed under the terms and conditions of the Creative Commons Attribution (CC BY) license (https:// creativecommons.org/licenses/by/ $4.0 /)$.

\begin{abstract}
This paper explores the role that the social economy, and the social business within it, have in terms of the strategies deployed to tackle Sustainable Development challenges. This paper proposes a New Sustainable Recovery Approach (NSRA) leveraging the strengths of the social economy and social business to guide policymakers to rethink socio-economic actions for a post-COVID-19 world aimed at sustainable human development. The NSRA is based on three, self-reinforcing, components: the promotion of Sustainable Human Development (SHD) for everyone; a transformative approach to Education and Research for individual and collective learning processes; and a strong emphasis on a recovery driven by an "enhanced social and environmental consciousness and behavior". The paper analyzes the role of the social economy and social business in the implementation of the NSRA. At the end of the paper, policy implications and final remarks are provided to policy makers.
\end{abstract}

Keywords: social business; social economy; sustainable development; human development; SDGs

\section{Introduction}

Right now, the whole world is discussing about how to face two global problems [1,2]: the health, economic and human crisis generated by the COVID-19 and how to restart the economy in a post-COVID-19 scenario whilst also addressing the larger issue of climate change.

Even before COVID-19 the world had many economic, social and environmental problems. Climate change threatens to destroy many of the planet's natural resources. Mass unemployment looms which might be alleviated in the short-medium term by artificial intelligence and technological advances, yet if these are not properly managed and geared towards benefiting humanity then the problems will continue. Wealth concentration is rapidly approaching explosive levels [3,4]. In recent years, we have frequently been obliged to remind ourselves that the current decade is, in fact, the decade of the last chance. The world is rapidly approaching a tipping point if we continue walking on the same path reaching the boundary in terms of environment and in terms of social wellbeing [5].

COVID-19 has quickly changed the context and trajectories of the world, exacerbated existing problems but also opened new possibilities which could not have existed before. In other words, we have a real opportunity to encourage a genuine change in how we live, produce, and consume. The responsibility for the latter to materialize is on all of us, citizens, governments, and companies. In theory, people and societies have tremendous freedom and capacities to turn our economies and societies towards a better world. However, this freedom does not lead to a sufficient effort to change things due to a lack of consciousness and sense of responsibility for the public good. Before restarting the economy, we should first reflect on what kind of economy and society we want, with respect to the distinction between means and goals [6] and between a "market society" [7] or a society where exchanges are regulated also by reciprocity and redistribution. First and foremost, the 
economy is a means to achieve the goals we set up. Hence, we should not allow the economy to transform us into passive subjects [6]. Conversely, we must continue designing and redesigning the economy until no one is left behind [8]. Therefore, the economy should be considered a mean to achieve the highest collective material as well as immaterial wellbeing. More broadly, we should ask ourselves: what vision of development should we pursue in a post-COVID-19 scenario? At the same time, however, if we want to challenge the pandemic impact in the short and the long run and move towards more sustainable development models, we should ask ourselves: how?

The Agenda 2030 for Sustainable Development represents a universal and overarching policy framework to address sustainable development from a multidimensional perspective, i.e., social, economic and environmental, and tackle all societal challenges. Indeed, the integrated and indivisible vision of sustainable development underlying the Agenda 2030, its Sustainable Development Goals (SDGs) and the relative targets have been translated into supranational, national and local strategies and policy initiatives for a better future. The sustainability transition requires a complementary perspective based on the role of local and territorial communities, extending the ecological conceptualization of resilience to socioecological systems [9]. This helps us to recognize as central concerns of transformative resilience (i) the evolving interaction between human beings and their environments and (ii) the relation between multidimensional vulnerabilities and economic, social and environmental shocks.

The objective of this paper is therefore to provide to policy makers a new perspective to follow, based on Social Economy and Social Business (SE\&SB) when drafting policies aimed at getting out of the crisis created by the COVID-19, but more generally, to steer our development path towards a more sustainable one. We are aware that the issue of sustainable development and policies to achieve it are complex and cannot be fully addressed in a single paper. That is why, when proposing our New Sustainable Recovery Approach (NSRA), we limit our work to the components of the approach we believe represent the main cornerstones of a sustainable development. In particular, we will explore how the SE\&SB can contribute to Sustainable Human Development (SHD) via an integrated approach. In doing so, we rely on literature coming from diverse fields and disciplines, from economics to behavioral sciences and psychology. In fact, we believe that the complexity of problems and their analysis and solution, cannot be addressed only relying on one discipline. The paper is structured into four main sections. The second section presents the NSRA and its three components: (a) SHD; (b) Transformative Education and Research for individual and collective learning processes; and (c) enhanced environmental and social consciousness and behavior (ESECB). The third section introduces the role that SE\&SB play in creating, enhancing, and reproducing the three components of the NSRA. In the fourth section, policy implications on how to support the role of SE\&SB in the NSRA, and promote the NSRA itself, are provided. In the last section the final remarks highlight the need and urgency for adopting the NSRA.

It is not the aim of this paper to get into definitional debates over the terms Social Economy, Social Enterprises and how these relate to Social Business. To navigate the different definitions and approaches we suggest the contributions of authors such as Defourny and Nyssens [10] and Bull and Ridley-Duff [11]. Hereafter we will clarify the definitions we use in the present work. When mentioning Social Economy, we refer to all economic activities conducted by enterprises, primarily cooperatives, associations and mutual benefit societies, whose ethics convey the following principles: 1. placing service to its members or to the community ahead of profit; 2 . autonomous management; 3 . a democratic decision-making process; 4 . the primacy of people and work over capital in the distribution of revenues". [12] (p. 19). We adopt Prof. Yunus' definition of Social Business that sets precise criteria for a company to be considered as such "companies that focus on providing a social benefit rather than on maximizing profit for the owners, and that are owned by investors who seek social benefits such as poverty reduction, health care for the poor, social justice, global sustainability, and so on, seeking psychological, emotional, 
and spiritual satisfaction rather than financial reward" [13]. Most importantly, any profit made by a Social Business stays within the company for further expansion or to make work conditions better for the workers, while investors get back only the funds they invested and cannot claim any dividends [14]. Social Businesses can be owned by anyone and adopt any governance structure if they are set up as market-based companies that have a social objective, are non-loss and non-dividend.

\section{The Main Components of a New Sustainable Recovery Approach}

In this challenging time, undoubtedly governments must continue with the recovery actions they had to undertake, such as taking care of the destitute and unemployed through traditional welfare programs, reviving healthcare and education systems, rejuvenating essential services, and supporting all possible actions to reduce the negative impact of the pandemic. So far, however, the separation of the 'economic' from the 'social' and from the 'environmental' discourse is inherent in the leader-follower hierarchy model of the orthodox economic policy recommendations. In these circumstances, social and environmental funds and education, health and environmental ministries are often left to take care of the consequences of economic policy mistakes-essentially to pick up the pieces $[15,16]$. In other words, we propose to focus on the opportunities of living and the collective processes that generate these socio-economic developments rather than on the means of living. In this respect, the essential idea is that social, economic and environmental arrangements should aim to expand people's capabilities (their freedom to promote and achieve valuable beings and doings) endorsing a sustainability perspective and generating transformative socioecological systems [9]. Moreover, Sen's [6] emphasis on what a person "has reason to value" opens up space for a democratic and non-paternalistic discourse on development visions, choices and strategies [17], with people conceived as active citizens rather than simply as consumers/beneficiaries. In Sen's [6] (p. 53) words, 'people have to be seen, in this perspective, as being actively involved-given the opportunity-in shaping their own destiny, and not just as passive recipients of the fruits of cunning development programs. Therefore, a new and more integrated and participatory approach might be necessary to change how we address societal challenges in the future. For this reason, we propose a NSRA to reach a higher level of sustainable development. The first component of the NSRA is SHD [16-18]. SHD can be defined as a process of promotion and expansion of valuable human capabilities (opportunities) where the term 'sustainable' refers to environmental and social sustainability [16]. SHD is both the end objective policy makers should aim for, and an approach that should be adopted by all actors involved in the development process (governments, businesses, citizens etc.). The second component, "Transformative Education and Research for individual and collective learning processes" can be defined as Education and Research that are aimed at sociotechnical systems transformation, meeting social needs and promoting sustainable and inclusive societies generating learning among and between different types of stakeholders. This component represents one of the main levers for transformative change in a postCOVID-19 world and in reaching the aims of SHD. It serves SHD both by educating citizens to understand sustainable development challenges and overcome them as well as removing challenges through the output of scientific research (a good example of this can be new materials that substitute plastic). The third component ESECB can be defined as a situation in which people are both knowledgeable about social and environmental issues and adopt prosocial and proenvironmental behaviors. It is the basis for, reinforces and provides direction to, the other two components. Without this component we would not have enough choices and behaviors that support SHD processes or a transformative research and education. All three components have positive feedback loops between them, which means that reaching a higher level in one component positively affects the other two components, conversely, a diminished level in one component negatively affects the other two components. For example, a drop in social and environmental consciousness and behavior would entail that a higher number of people do not care of the environment 
and society. They could therefore adopt consumption habits that totally disregard social and environmental issues, which in turn could advantage companies that do not respect worker's rights and pollute. At the end, this will negatively affect SHD. As will be later shown in the paper, SE\&SB play a key role in reinforcing the overall structure of the NSRA and the feedback loops between the different components. This key role of SE\&SB is represented in Figure 1 where SE\&SB are in the middle of the wider triangle made by the three main components and serve as a connection between the three.

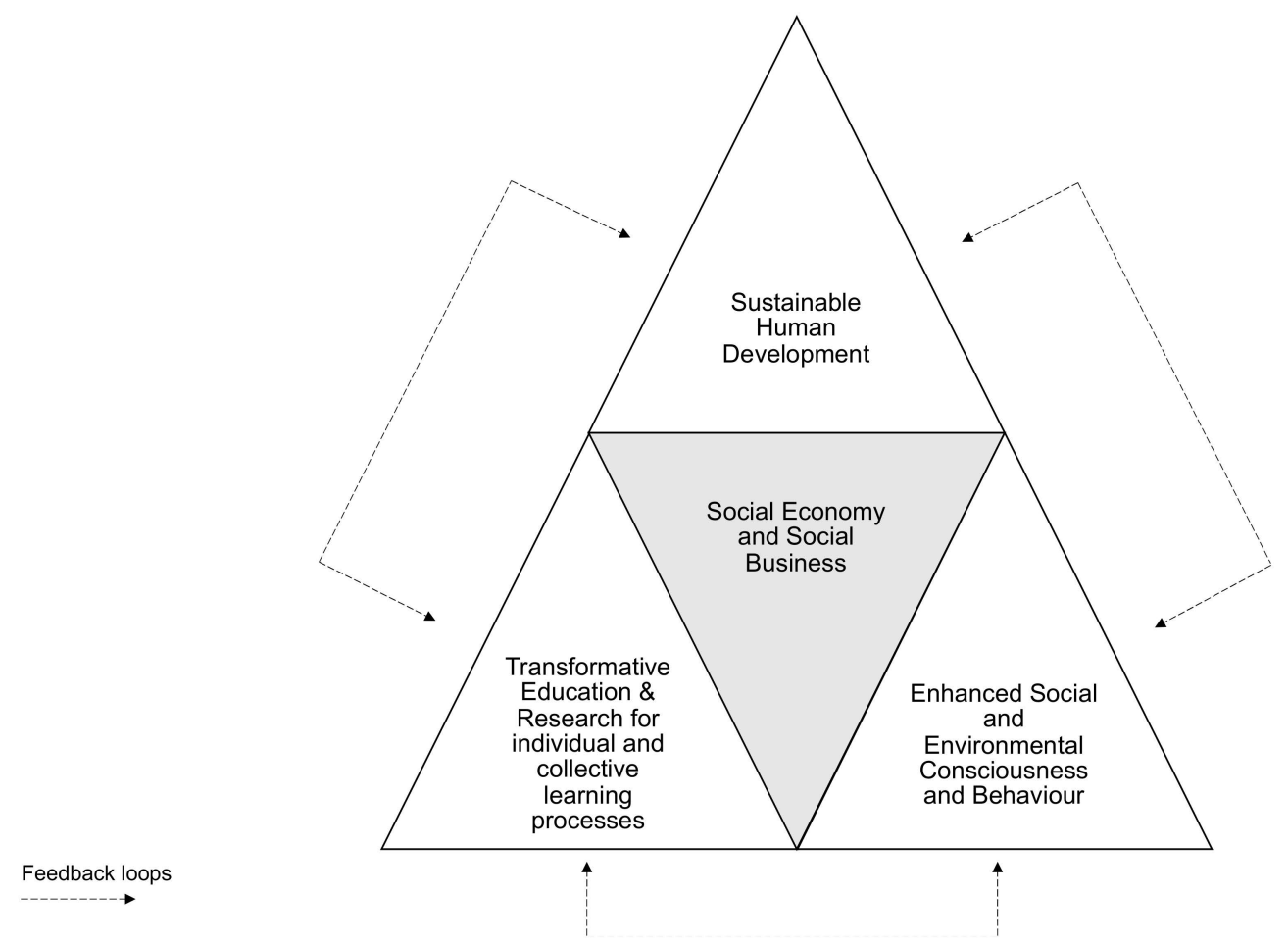

Figure 1. The components of the New Sustainable Recovery Approach.

\subsection{Sustainable Human Development}

In line with the Agenda 2030 and the SDGs, the first component for a NSRA is the necessity to adopt a SHD vision. Human well-being, participation and freedom must be the central economic and social goal [6] as 'the basic objective of development is to create an enabling environment for people to enjoy long, healthy and creative lives' [19] (p. 9).

The SHD approach is based on four pillars [18]:

- Equity for all, in terms of political, economic, social and cultural opportunities, as well as distribution, inclusion and cohesion;

- Participation and empowerment of citizens, conceived as being active individual and collective agents of their own future(s), placing human beings and communities at the core of development processes through citizenship, solidarity, respect and responsibility;

- Sustainability, concerning equal intergenerational opportunities in environmental, social and economic terms, and conceived not as a cost but rather as an essential feature of sustainable and environmentally friendly development;

- Productivity, pursuing an efficient use of local resources within production systems necessary for societal objectives.

In a world shocked by the COVID-19 pandemic, an appropriate and effective recovery strategy must be based on both the stronger involvement and deeper commitment of individuals, embedded in local communities (i.e., the "participation" principle of SHD), nurtured by relations with proximate others and integrated in systems of solidarity (i.e., the "equity" principle). It also involves recognizing that the economic and production 
systems (i.e., the "productivity" principle) must be reoriented to serve social well-being (as it has been, for example, to address health and education issues in recent startling times). Ultimately, this involves recognizing that investments in basic social services and environmental protection are not primarily costs but, instead, fundamental contributions to protect our lives (i.e., the "sustainability" principle). On top, this component requires an alliance towards this vision at all levels. Adopting a SHD approach in policy making means to address the inherent differences of individuals, in terms of their needs, preferences and capabilities by providing as much as possible tailored solutions. This means building welfare systems that can be easily adapted to changing preferences and needs and react to new challenges (such as the one that arose with COVID-19). Such an objective is challenging since it entails moving from a rigid welfare system usually aiming at reaching economies of scale by providing standardized answers to problems, to a system that is efficient, effective as well as flexible. There is therefore a need to rethink how policies are drafted by effectively operationalizing all SHD principles while achieving a greater system's flexibility. To achieve this, policy makers could, for example, leverage the power of new technologies to increase access to services and facilitate citizens' participation in the public sphere, favor the democratization of production processes by promoting a shared ownership of the companies and their benefits, find more sustainable solutions to human activities, and raise the productivity of local resources. It is important to underline that some elements of SHD, such as education and health, are at the same time the final objective to be reached but have also an instrumental value and can be means to reach a higher level of SHD. In the NSRA, for example, SHD contributes to reaching higher levels of the other two components. In the case of "Transformative Education and Research for Individual and Collective Learning Processes" a higher level of SHD in a society increases the society's capacity to further educate its citizens and perform R\&I activities whilst also making access to education more equitable. This also means creating the condition for a larger participation of different stakeholders to R\&I activities and their capacity to use R\&I results. SHD can also contribute to an ESECB. SHD in a society is positively related to the capacity of its citizens to understand and interpret reality and understand which behaviors, actions and policies are harmful for the society and the environment. This consciousness could increase pro-social behaviors at all levels of society.

\subsection{Transformative Education and Research for Individual and Collective Learning Processes}

Fostering a common effort involves, first, starting with individuals' capabilities by promoting consciousness and responsibility, then, building active citizenship and participation at the community level. This can be achieved through new education systems fostering critical, creative thinking among the 'new' citizens [20] as well as entrepreneurial thinking [21]. Indeed: "The development of a democratic society implies the promotion of critical, creative and caring thinking in its citizens. This will enhance their autonomy and, at the same time, open their minds to confrontation with different perspectives and points of view" [22] (p. 374). This component requires re-thinking, in most countries, the Education and Research systems and how they engage with individuals and communities to bring to individual and collective learning processes aimed at facing changes and challenges and at facilitating transformative resilience. New framings and creative solutions are needed for recovering and enhancing education systems. On the one hand, we should work on access to education, especially in poor communities living in remote areas and urban slums, for example by taking advantage of current and future technical opportunities (e.g., distant learning). On the other, the education process not only involves education institutions, such as schools and universities, but also the community. Therefore, education efforts should also be targeted to the community. An educated community can more easily support and reinforce institutional education processes. Once given the possibility to children, youth and communities, to access learning and education, it is not just a question of going back to a pre-pandemic educational system using new technological tools. We should also redefine the end results of the education system. Already Durkheim [23] declared 
that the 'aim of public education is not 'a matter of training workers for the factory or accountants for the warehouse but citizens for society" or as Noddings says [24] (p. 27) "to encourage the growth of competent, caring, loving, and lovable people", or in the words of Cochran-Smith [25] (p. 116) individuals mindful of 'social responsibility, social change, and social justice' (see also [26]). Even nowadays, given we have more advanced societies, we should aim to produce capable agents and communities and new competences and skills which are, indeed, needed to face future challenges and the speed with which these challenges will occur. These skills and competencies should include not only the acquisition of new technical skills such as informatics or relational competencies (communicative competences-[27] but also competencies such as 'complex thinking' -indeed, preparing students to navigate complexity in this turbulent world-[28-30], encompassing dialogical and argumentative attitudes and practice as well as fostering their "Locus of control" that represents an individual's perception of whether he or she has the ability to bring about change through his or her own behavior [31]. The locus of control is directly connected to the third component of the NSRA approach ESECB; a shift towards a learning-centered approach in which children and youth (and learners in general), are considered active, aware, and responsible builders of their own understanding, knowing and growing [32]. In particular, promoting children's and youth active participation in society, starting from when they first get into the education system, means on one side socializing them towards an understanding of their own competencies and an understanding of the reality, and problems, that surround them. On the other side, it means also fostering responsibility and an entrepreneurial attitude by enhancing skills in planning, designing, monitoring and managing social contexts. On the research and innovation (R\&I) side, there is the need to promote R\&I policies that adopt a "transformative change framework" as proposed by Schot and Steinmueller [33]. In this framework R\&I should be aimed at socio-technical systems transformation. Science, technology, and innovation should be geared towards meeting the social needs while promoting sustainable and inclusive societies. This doesn't mean just innovating with the assumption that all research and technological innovation will be good for sustainability, but it means questioning how research and innovation can contribute to sustainability and under which conditions (this could be the case, for example, of artificial intelligence and the changes it might bring to the labor market). It means also shifting from a focus on technical innovation to social innovation [34] and considering that innovations and solutions to social problems, especially in the case of social entrepreneurship, can be the result of the actions of individuals and groups embedded in supportive networks and communities $[35,36]$. This implies widening the perspective not only to the direct "generators" of the innovation but to the ecosystem as a whole. As Schot and Steinmueller point out, there is the need for inclusive deliberation processes and basing policies on new knowledge bases not dominated by economics and innovation studies but more interdisciplinary including governance, history of technology and other fields [33] (p. 1564). Therefore, a transformative and change framework should promote participation of different stakeholders, an interdisciplinary approach and a focus on socio-technical system transformation to reach the SDGs. A structured participation of different stakeholders (for-profit companies, social businesses, public authorities) into R\&I as well as in the education system could improve collective learning processes and bridge the gap that often arises between the research and education system and the productive one [37-40]. Moreover, since direct experience has a higher influence in changing peoples' behavior [41], the participation of stakeholders involved in some of the many challenges we are facing could also lead to an increase of learning approaches based on first-hand experiences geared towards the enhancing of social and environmental consciousness and behavior.

\subsection{Enhanced Social and Environmental Consciousness and Behavior}

The literature on psychology and behavioral economics have delved deep into altruism, empathy compassion and attitudes, intentions, and prosocial behaviors [42-46]. It is 
beyond the scope of this paper to provide an exhaustive literature review of the relations between these elements. For the sake of our discussion, we will therefore oversimplify the topic by defining ESECB, as a situation in which people are knowledgeable about social and environmental issues, show great altruism, empathy, compassion, and tend to adopt prosocial and proenvironmental behaviors. This 'inner' component of the NSRA is at the same time a prerequisite for reaching the other two components and is also dependent upon them. For example, in relation to the SHD component, ESECB makes people act following the SHD principles but at the same time a higher level of SHD could influence the ESECB via a more educated citizenry. An ESECB is necessary for the education system to redefine its end results, but also in redesigning the education system itself by "ensuring inclusive and equitable quality education and lifelong learning opportunities for all" as stated in Goal 4 of the Global Goals. Concerning R\&I, ESECB can help in gearing the efforts towards social and environmental objectives but also in critically questioning if the innovation process is bringing the intended benefits to the environment and society and a higher attention to the immaterial aspects of our lives. ESECB could also represent a common ground of understanding between experts of different disciplines and thus contribute to a transformative R\&I framework. To fully reach the first two components and reinforce and nurture them over time, it is therefore necessary that our society acquires, and maintains over time, this ESECB at all levels (policy makers, businesses, citizens). Studies like the one from Kollmuss and Agyeman [47] show that knowledge of social and environmental issues is only one of the many factors influencing peoples' behavior. Our society needs therefore not only to educate citizens but also create institutions, incentives and a culture that promote and reward prosocial and proenvironmental behaviors.

\section{The Role of the Social Economy and Social Business in the NSRA}

Hereafter we explore the relation between SE\&SB and each component of the NSRA.

\subsection{SEESB and SHD}

The distinctive features of SE\&SB lie in their potential to equally embrace in their vision, model and operational mechanism the four principles of SHD. In fact, SE\&SB can contribute to SHD [48,49] and in reaching the SDGs [50] via the services and products they offer and through the production and consumption processes they enable. Since the focus of their activity is not on profit maximization, efficiency and effectiveness are achieved mainly by considering the social impact they produce. For this reason, their inputs, activities and outputs (products and services) focus on accessibility, inclusiveness and environmental sustainability, often generating higher benefits to the community and the environment compared to the same services/products delivered by other types of organizations. Moreover, due to limits to profit redistribution, in most cases profits and surpluses directly benefit the members or the beneficiaries of the organization. A relevant aspect for SHD of SE\&SB organizations is their multi-stakeholder and participatory governance processes and redistributive function [51]. For this reason, SE\&SB organizations are more efficient and equitable collectors, organizers and distributors of resources to solve social or environmental problems than other organizations. In fact, SE\&SB, as per their business model, need to engage with different stakeholders with whom they can share information, cooperate on delivering services and products, start advocacy campaigns etc. Adopting a multi-stakeholder and participatory approach makes them inherently more capable of building relations with, and among, different stakeholders, as well as creating a shared view of development and thus contributing, for example, to localize the SDGs in a territory. In fact, participation gives to stakeholders the possibility to express their intentions and preferences and facilitates coordination among various interest groups [52] (an interesting example of an organization adopting a multistakeholder approach is the Fondazione di Comunità di Messina (Community Foundation of Messina) in Sicily, Italy. The Foundation collects and organizes national and local resources for strategic investments aimed at supporting local programs, projects and entrepreneurial activities. The 
Foundation moreover provides them with the opportunities, means and funding to become self-sustainable and of generating, in turn, social and environmental impact.). SE\&SB organizations can effectively complement the traditional welfare systems by supplying the tailored services, which cannot be provided by the larger and standardized public providers. This can be possible due to the proximity of SE\&SB organizations to local communities, their higher flexibility and capacity to experiment, if compared to public authorities, and their need to be more capable of answering to the client/beneficiaries' problems. Creating a formalized role of SE\&SB in the welfare system does not mean privatizing the system but, rather, incentivize public-private partnership between public authorities and SE\&SB organizations to co-produce certain services (e.g., elderly care, transport for people with disabilities etc.). However, for this to be successful, it is important that policy makers create a system that does not create monopolistic or oligopolistic advantages for SE\&SB, promotes a competition based on social value and not on lower prices and gives to SE\&SB the legal instruments to co-create services with public authorities.

\subsection{SEESB and REI and Education}

The relation between SE\&SB organizations with the education system is twofold. On one side, SE\&SB organizations can have a primary role in increasing access to education (for example many A-type Social Cooperatives in Italy work on education complementing the offer provided by the education system and reaching particular target groups (young people with disabilities, immigrant students at high risk of an early drop-out etc.)) of underprivileged communities or in filling in some of the gaps of the country's education system using innovative approaches in teaching. On the other side, the education system can use SE\&SB education to promote the ESECB (This is for example the final aim of the educational program "Youth and Social Business" adopted in some high schools in Pistoia (Italy) in the framework of the Social Business City Program implemented by the Yunus Social Business Centre University of Florence, Fondazione Cassa di Risparmio di Pistoia e Pescia and Fondazione Un Raggio di Luce). Li and Yuan [53] state that social entrepreneurship education for high school students in China could "reshape the morality of college students", "promote innovative thinking of students" and "cultivate consciousness of high school students of sustainable human development". Hockerts [54] reveals that social entrepreneurship education increases self-efficacy, perceived social support and social entrepreneurial intentions of master-level elective courses students but has no significant effect on empathy and moral obligations. Moreover, Kedmenec et al. [55] show how teaching SE\&SB can have a positive impact in social entrepreneurial intentions. This could lead, on the long term, to a higher number of SE\&SB organizations. The relation between SE\&SB organizations and R\&I depends on the overall ecosystem in which R\&I organizations and SE\&SB organizations are set. In particular, on how the information is shared between the different actors of the system and the degree of coordination and cooperation among them. SE\&SB usually operate at the local level and therefore maintain a strong connection with the locality in which they are embedded, both in terms of positive contribution to the locality [56,57], as well as in terms of the resources they use in their activities [58-62]. Their proximity to problems makes them understand what works and what doesn't in the local context, and thus are particularly well-suited to respond quickly to issues that arise in their local areas [63]. This feature is particularly valuable for creating and maintaining transformative R\&I and Education systems since it can provide first-hand knowledge on social and environmental issue to R\&I actors such as public authorities or Universities. Moreover, the connection with the locality and the innovative approach to solving problems of some SE\&SB organizations can further stimulate innovation in the R\&I system, for example by giving the possibility to research institutions to pilot test new products and services for the benefit of the community or the environment. For this to happen there is the need to create systems that promote information sharing and coordinating and cooperating mechanisms. Under this regard, the current experiments in Italy of public service co-planning between social economy organizations and public authorities, 
with the occasional participation of other organizations such as research institutions, could represent one of the possible models for information sharing, coordination and cooperation between actors of the system.

\subsection{SEESB and Enhanced Social and Environmental Consciousness and Behavior}

The relation between SE\&SB and the ESECB is twofold. On one side the ESECB contributes to the birth and growth of SE\&SB organizations, on the other side SE\&SB are useful in fostering and keeping a higher level of ESECB in a territory. SE\&SB are usually founded by single or groups of social entrepreneurs. The research on the motivations of social entrepreneurs to start such organizations [64-70] shows that most of these motivations fall into the ESECB. Motivations to start SE\&SB are positively influenced by the ESECB. For example, a study from Sana et al. [71], shows that students with higher "compassion" and "loving-kindness meditation" are more motivated towards social entrepreneurship. SE\&SB can also positively influence the ESECB in a society. This can be achieved through public agency and advocacy [72]; by influencing peoples" "locus of control" for example by providing real-life examples of how problems can be successfully addressed by people; by including disadvantaged people into the labor market and increasing the perception of social issues and diversity among workers and clients. Most importantly, in areas where SE\&SB organization that compete on the market with traditional for-profit enterprises, have enough market share, there could be a shift from a competition based on price to one based on social value or the access offered to different types of wealth [73]. In this field, an important role is played by public authorities when they set the criteria for awarding public tenders and could therefore favor social value rather than price [74], and by actions, such as communication campaigns, that aim at changing the preferences of consumers towards products and services with a higher social value [75].

\section{Policy Implications and Recommendations}

So far, we have explored the contribution of SE\&SB to the NSRA. We now present the policy recommendations to support SE\&SB development whilst creating synergies to generate a transformative process. A first set of policies has the aim of increasing the number of SE\&SB organizations in the country by creating an enabling system for SE\&SB. The rationale for this can be found in the following aspects. A higher number of SE\&SB organizations can: have a positive effect on the ESECB, shift competition more on social value rather than price, contribute to advocate for social issues and change consumers perspectives, need support services and create a rich support ecosystem that increases their birth, growth and survival rates. We are aware that policies to increase the number of SE\&SB organizations depend on the country, its legal framework, the resources and the level of development of the SE\&SB ecosystem. We therefore propose a series of actions that do not have the objective to cover all possible cases but can be applicable in almost all countries. These actions contribute to create an enabling eco-system for SE\&SB and complement each other by creating positive synergies $[49,75]$. First, it is important to create a comprehensive and flexible set of financing options such as grants, investment, social impact bonds, to cover the different development stages and sectors of activity of SE\&SB organizations [49]. Second, there should be a focus on creating legal frameworks that recognize SE\&SB organizations. The history of social cooperatives in Italy that have been legally recognized in 1991 but had already been operating in the previous 20 years [75], shows that legal frameworks are not fundamental for SE\&SB organizations to exist, as they will using existing legal forms. However legal frameworks are important to create targeted policies such as fiscal reliefs, specific clauses in public procurement $[10,76]$, for the sector's recognition but also to avoid the shortfalls of having to use legal forms that do not completely fit in the SE\&SB scope and objectives [77] [10,78]. Third, encourage traditional companies to become SE\&SB themselves or take in SE\&SB partners or create their own SE\&SB for example for managing corporate's welfare. This process could be incentivized by providing tax reliefs for the investment in setting up a SE\&SB organization 
or for corporate restructuring. In the case of companies that are being closed by the owners, for example, because they are not deemed being profitable enough, governments should finance the buyout from workers at the condition that those companies will become SE\&SB organizations. This could also reduce the problem of unemployment. Fourth, create new markets for SE\&SB. This can be achieved by increasing the types of tenders to which SE\&SB can take part to, as well as in promoting sustainable consumption models among companies and the overall population. Finally, establish courses at all levels of the education system in which the topics of SE\&SB are thought also through experiential learning approaches at community and collective level.

Another set of policy advice concerns how policy makers can make the most of SE\&SB organizations in their territory. In fact, as discussed by Testi et al. [74] the presence of SE\&SB in a territory does not automatically mean that they are producing as much social or environmental value as they could. This can be the result of a plethora of factors such as competition, capacity of social entrepreneurs, non-favorable legal framework on SE\&SB activities etc. The following policies are targeted to reduce or remove such hindering factors. First, public authorities at all levels should promote multilevel governance processes and legal frameworks in which SE\&SB are formally included in sharing information and coplanning services and solutions with public actors. This will improve the understanding of problems at all levels and among stakeholders and increase the possibilities to find and provide innovative and tailored solutions. Second, keep competition among SE\&SB organizations and between SE\&SB and traditional for-profit companies on a fair level by offering incentives (these could be in terms of award criteria in tenders, fiscal advantages etc.) to social and environmental value creation. Third, ease the legal framework in areas related to SE\&SB activities. This does not concern the legal framework of SE\&SB per se (as seen above) but, for example, the rules to employ disadvantaged people, or easing the administrative burden connected to obtain certain resources or to implement certain activities etc. Fourth, co-fund or de-tax investments of SE\&SB, for example in terms of marketing or technological advances, for these organizations to grow faster. Finally, co-fund education and capacity building for human resources working in SE\&SB organizations in order for them to be more efficient and effective in their work.

The last set of policies are directly aimed at reinforcing the role of SE\&SB inside the NSRA or one specific component of the NSRA are linked to the government role and the willingness of policymakers. Governments should not only promote education on SE\&SB at all education levels, but they should also improve connections between R\&I institutions and SE\&SB. This could be achieved through special research grants that have as a prerequisite the involvement of SE\&SB organizations, or conversely, by including in tenders to which SE\&SB organizations apply, the need to have a R\&I institution inside the partnership. Governments should also create incentives for prosocial and proenvironmental behaviors in all daily activities conducted by citizens. For this, behavioral economists, anthropologist, psychologist, experts in service design, communication experts and all other relevant experts, should be consulted before planning new initiatives. All new services, activities, projects, and policies should integrate features that promote prosocial and proenvironmental behaviors among the population so that, in the long run, prosocial and proenvironmental behaviors become the norm. Governments should promote multilevel governance processes aimed at sustaining SDGs localization including different actors. This could entail for instance creating easily accessible participatory platforms (also digital ones) for different stakeholders to actively take part in policy making and not only have a consultative role. Lastly, government should also open R\&I policy to stakeholders involved in social and environmental issues to focus R\&I on solving the most pressing societal and environmental problems [79].

\section{Final Remarks}

Global citizens should be assured that the next development strategies will be different from the past ones. Re-establishing businesses-as-usual will not be a true recovery strategy. 
Instead, a recovery oriented towards people and the planet is seriously needed. Following the Agenda 2030, governments should guarantee that all resources will bring the maximum social and environmental benefit to society. All the recovery actions must lead to the creation of a socially and environmentally conscious economy for the country, as well as for the world. Out of the desperation and urgency of the COVID-19 situation a right call from governments can create a surge of activities the likes of which have never been known before. A test of leadership will be to show how a world can be inspired to be re-born in completely unknown ways, coming from the youths, the middle-aged, and the elderly, men, and women. If we fail to undertake social and environmental consciousness driven post-COVID-19 recovery programs we will be heading (if present trends continue), for far worse forms of catastrophe than the current pandemic has bestowed upon us. Most of us, at least those lucky enough to have the opportunity to do it, have been hiding in our homes from coronavirus, but if we fail to address deteriorating global issues, we will no longer have any place to hide from the biggest problems such as climate change. We are aware that when discussing how to develop our societies in a more sustainable way there could be many entry points and strategies. In our approach, we therefore tried to consider the main components, the cornerstones, that are necessary to move on a sustainable development path. For this reason, in this paper we proposed a NSRA based on three components: SHD for everyone; a transformative approach to Education and Research for individual and collective learning processes to face changes and challenges; and a strong emphasis on a recovery driven by an ESECB. We also highlighted how SE\&SB organizations can play a central role in such approach and what concrete policies can be drafted to reinforce both their role and the single components of the NSRA. The alternative is within our reach and requires only the courage to relentlessly pursue the goal of human flourishing, thus turning the future into a new renaissance for our people, our communities and our planet.

"... things are never as complicated as they seem. It is only our arrogance that prompts us to find unnecessarily complicated answers to simple problems". -Muhammad Yunus

Author Contributions: Conceptualization, M.Y., M.B. and E.T.; writing—original draft, M.B. and E.T.; writing-review and editing, M.Y., M.B. and E.T. All authors have read and agreed to the published version of the manuscript.

Funding: This research received no external funding.

Data Availability Statement: No new data were created or analyzed in this study. Data sharing is not applicable to this article.

Conflicts of Interest: The authors declare no conflict of interest.

\section{References}

1. Anand, P.; Ferrer, B.; Gao, Q.; Nogales, R.; Unteerhalter, E. COVID-19 as a Capability Crisis: Using the Capability Framework to Understand Policy Challenges. J. Hum. Dev. Capab. 2020, 21, 293-299. [CrossRef]

2. Fuentes, R.; Galeotti, M.; Lanza, A.; Manzano, B. COVID-19 and Climate Change: A Tale of Two Global Problems. Sustainability 2020, 12, 8560. [CrossRef]

3. Fleurbaey, M.; Bouin, O.; Salles-Djelic, M.-L.; Kanbur, R.; Nowotny, H.; Reis, E.; Sen, A. A Manifesto for Social Progress; Cambridge University Press (CUP): Cambridge, UK, 2018.

4. Donald, K.; Martens, J. The Increasing Concentration of Wealth and Economic Power as an Obstacle to Sustainable DevelopmentAnd What to Do about it. Spotlight on Sustainable Development 2018: Exploring new policies pathways. Available online: https://www.2030spotlight.org/sites/default/files/spot2018/chaps/Spotlight_Innenteil_2018_chapter1_donald.pdf (accessed on 30 October 2021).

5. Raworth, K. Doughnut Economics: Seven Ways to Think Like a 21st Century Economist (2017). Reg. Bus. Stud. 2019, 11, 81-86.

6. Sen, A.K. Development as Freedom; Oxford University Press: Oxford, UK, 2009.

7. Polanyi, K. The Great Transformation: The Political and Economic Origins of Our Time; Beacon Press: Boston, MA, USA, 2001.

8. United Nations. Transforming Our World: The 2030 Agenda for Sustainable Development; Resolution Adopted by the General Assembly of the United Nations (A/RES/70/1); United Nations: New York, NY, USA, 2015.

9. Walker, B.; Holling, C.S.; Carpenter, S.R.; Kinzig, A. Resilience, Adaptability and Transformability in Social-ecological Systems. Ecol. Soc. 2004, 9. Available online: https://www.ecologyandsociety.org/vol9/iss2/art5/ (accessed on 30 October 2021). [CrossRef] 
10. Defourny, J.; Nyssens, M. Fundamentals for an International Typology of Social Enterprise Models. Volunt. Int. J. Volunt. Nonprofit Organ. 2017, 28, 2469-2497. [CrossRef]

11. Bull, M.; Ridley-Duff, R. Towards an Appreciation of Ethics in Social Enterprise Business Models. J. Bus. Ethic 2019, 159, 619-634. [CrossRef]

12. Defourny, J.; Develtere, P. The social economy: Worldwide making of a third sector. In L'économie Sociale au Nord et au Sud; De Boek Université: Paris, France, 1999; pp. 15-40.

13. Yunus, M. Creating a World Without Poverty; Public Affairs: New York, NY, USA, 2007.

14. Yunus, M. Building Social Business. Capitalism that Can Serve Humanity's Most Pressing Needs; Public Affairs: New York, NY, USA, 2020.

15. Mehrotra, S.K.; Delamonica, E. Eliminating Human Poverty: Macroeconomic and Social Policies for Equitable Growth; Zed Books: London, UK, 2007; Volume 1, pp. 84274-84777.

16. Biggeri, M.; Ferrannini, A. Sustainable Human Development: A New Territorial and People-Centred Perspective; Palgrave Macmillan: New York, NY, USA, 2014.

17. Clark, D.A.; Biggeri, M.; Frediani, A.A. Sen's Capability Approach, Empowerment and Participation: Concepts, Methods and Applications; Palgrave MacMillan: New York, NY, USA, 2019.

18. Haq, M. Reflections on Human Development; Oxford University Press: Oxford, UK, 1995.

19. UNDP. Human Development Report 1990. Concept and Measurement of Human Development; Oxford University Press: New York, NY, USA, 1990; p. 9.

20. Nussbaum, M.C. Creating Capabilities: The Human Development Approach and Its Implementation. Hypatia 2008, 24, 211-215. [CrossRef]

21. Yunus, M. A World of Three Zeros: The New Economics of Zero Poverty, Zero Unemployment, and Zero Net Carbon Emissions; Public Affairs: New York, NY, USA, 2017.

22. Biggeri, M.; Santi, M. The Missing Dimensions of Children's Well-being and Well-becoming in Education Systems: Capabilities and Philosophy for Children. J. Hum. Dev. Cap. 2012, 13, 373-395. [CrossRef]

23. Durkheim, E. Social Property and Democracy: Review of Alfred Fouille, La Propriete et la Democratie (Paris, 1884). In Durkheim on Politics and the State; Durkheim, E., Ed.; Stanford University Press: Stanford, CA, USA, 1885; pp. 86-96.

24. Noddings, N. Thinking about Standards. Phi Delta Kappa 1997, 79, 184-189.

25. Cochran-Smith, M. Learning to Teach for Social Justice. In The Education of Teachers: Ninety-Eighth Yearbook of the National Society for the Study of Education; Griffin, G., Ed.; University of Chicago Press: Chicago, IL, USA, 1999; pp. 114-144.

26. Halvorsen, R.; Hvinden, B.; Biggeri, M.; Tassebro, J.; Jarvis, C.E.; Waldschmidt, A. Lived Experiences of Persons with Disabilities: Active Citizenship and Disability in Europe; Routledge: London, UK, 2017; Volume 2.

27. Funk, N.; Habermas, J.; McCarthy, T. The Theory of Communicative Action. Vol. 1: Reason and the Rationalization of Society. Philos. Rev. 1986, 95, 269. [CrossRef]

28. Stacey, R.D. Strategic Management and Organisational Dynamics: The Challenge of Complexity to Ways of Thinking about Organisations; Pearson education: Harlow, UK, 2007.

29. McMillan, E. Complexity, Organizations and Change; Routledge: London, UK, 2003.

30. Lipman, M. Thinking in Education; Cambridge University Press (CUP): New York, NY, USA, 2003.

31. Newhouse, N. Implications of Attitude and Behavior Research for Environmental Conservation. J. Environ. Educ. 1990, 22, 26-32. [CrossRef]

32. Dehler, G.E. Prospects and Possibilities of Critical Management Education: Critical Beings and a Pedagogy of Critical Action. Manag. Learn. 2009, 40, 31-49. [CrossRef]

33. Schot, J.; Steinmueller, W.E. Three frames for innovation policy: R\&D, systems of innovation and transformative change. Res. Policy 2018, 47, 1554-1567. [CrossRef]

34. Osburg, T.; Schmidpeter, R. Social Innovation. Solutions for a Sustainable Future; Springer: Berlin, Germany, 2013.

35. Ellerman, D. Entrepreneurship in the Mondragon Cooperatives. Rev. Soc. Econ. 1984, 42, 272-294. [CrossRef]

36. McMullen, J.S. Are we confounding heroism and individualism? Entrepreneurs may not be lone rangers, but they are heroic nonetheless. Bus. Horizons 2017, 60, 257-259. [CrossRef]

37. Farooq, S. Mismatch Between Education and Occupation: A Case Study of Pakistani Graduates. Pak. Dev. Rev. 2011, 50, 531-553. [CrossRef]

38. Stanef, R.M.; Manole, A.M. Educational System Gaps in Romania. Procedia-Soc. Behav. Sci. 2013, 93, 794-798. [CrossRef]

39. Falcke, S.; Meng, C.; Nollen, R. Educational mismatches for second generation migrants. An analysis of applied science graduates in the Netherlands. J. Ethn. Migr. Stud. 2020, 46, 3235-3251. [CrossRef]

40. Ashmarina, S.I.; Kandrashina, E.A.; Izmailov, A.M.; Mirzayev, N.S. Gaps in the system of higher education in Russia in terms of digitalization. In Digital Transformation of the Economy: Challenges, Trends and New Opportunities; Springer: Cham, Switzerland, 2020; pp. 437-443. [CrossRef]

41. Rajecki, D.W. Attitudes: Themes and Advances; Sinauer Associates: Sunderland, MA, USA, 1982.

42. Bar-Tal, D. Prosocial Behavior: Theory and Research; Hemisphere Publishing Corp: New York, NY, USA, 1976.

43. Beilin, H.; Eisenberg, N. The Development of Prosocial Behavior; Academic Press: New York, NY, USA, 2013.

44. Padilla-Walker, L.M.; Carlo, G. The Study of Prosocial Behavior. Prosocial Dev. 2014, 3, 3-16. [CrossRef] 
45. Kristeller, J.L.; Johnson, T. Cultivating Loving Kindness: A Two-Stage Model of the Effects of Meditation on Empathy, Compassion, and Altruism. Zygon 2005, 40, 391-408. [CrossRef]

46. Schroeder, D.A.; Graziano, W.G.; Batson, C.D.; Lishner, D.A.; Stocks, E.L. The Empathy-Altruism Hypothesis. In The Oxford Handbook of Prosocial Behavior; Oxford University Press (OUP): Oxford, UK, 2015; pp. 259-281.

47. Kollmuss, A.; Agyeman, J. Mind the Gap: Why do people act environmentally and what are the barriers to pro-environmental behaviour? Environ. Educ. Res. 2002, 8, 239-260. [CrossRef]

48. Scarlato, M. Social Enterprise and Development Policy: Evidence from Italy. J. Soc. Entrep. 2012, 3, 24-49. [CrossRef]

49. Biggeri, M.; Testi, E.; Bellucci, M. Enabling Ecosystems for Social Enterprises and Social Innovation: A Capability Approach Perspective. J. Hum. Dev. Capab. 2017, 18, 299-306. [CrossRef]

50. Littlewood, D.; Holt, D. Social Entrepreneurship in South Africa: Exploring the Influence of Environment. Bus. Soc. 2018, 57, 525-561. [CrossRef]

51. Borzaga, C.; Defourny, J. Conclusions. Social enterprises in Europe: A diversity of initiatives and prospects. In The Emergence of Social Enterprise; Borzaga, C., Defourny, J., Eds.; Routeledge: London, UK, 2001; pp. 350-370.

52. Ben-Ner, A.; Gui, B. The Theory of Nonprofit Organizations Revisited; Kluwer Academic/Plenum Publishers: New York, NY, USA, 2003; pp. 3-26.

53. Li, L.; Yuan, F. Integrating Social Entrepreneurship into Higher Education in the New Era. In Proceedings of the 2019 3rd International Conference on Education, Economics and Management Research (ICEEMR 2019), Singapore, 29-30 November 2019; Atlantis Press: Singapore, 2020; Volume 10, pp. 163-168.

54. Hockerts, K. The Effect of Experiential Social Entrepreneurship Education on Intention Formation in Students. J. Soc. Entrep. 2018, 9, 234-256. [CrossRef]

55. Kedmenec, I.; Rebernik, M.; Tominc, P. Social Entrepreneurship Education and Its Association with Perceived Desirability and Feasibility of Social Entrepreneurship among Business Students. Croat. J. Educ. 2017, 18, 1035. [CrossRef]

56. Borzaga, C.; Tortia, E. Social enterprises and local economic development. In The Changing Boundaries of Social Enterprises; Clarence, E., Noya, A., Eds.; OECD Publishing: Paris, France, 2009; pp. 195-228.

57. Birkhölzer, K. The role of social enterprise in local economic development. In Proceedings of the 2nd EMES International Conference on Social Enterprise, Trento, Italy, 1-4 July 2009.

58. Evers, A.; Schulze-Boeing, M. Germany: Social Enterprises and Transitional Employment. In The Emergence of Social Enterprise; Borzaga, C., Defourny, J., Eds.; Routledge: London, UK, 2011; pp. 120-135.

59. Hynes, B. Growing the social enterprise-Issues and challenges. Soc. Enterp. J. 2009, 5, 114-125. [CrossRef]

60. Pasetto, A. Imprese Sociali e Sistemi Produttivi Locali. In Rivista dell'Associazione Rossi-Doria; Franco Angeli: Milan, Italy, 2011; Volume 3, pp. 149-166.

61. Di Domenico, M.; Haugh, H.; Tracey, P. Social Bricolage: Theorizing Social Value Creation in Social Enterprises. Entrep. Theory Pract. 2010, 34, 681-703. [CrossRef]

62. Eversole, R.; Barraket, J.; Luke, B. Social enterprises in rural community development. Commun. Dev. J. 2013, 49, $245-261$. [CrossRef]

63. OECD. Social Economy and the COVID-19 Crisis: Current and Future Roles; OECD: Paris, France, 2020.

64. Thake, S.; Zadek, S. Practical People, Noble Causes. How to Support Community Based Social Entrepreneurs; New Economic Foundation: London, UK, 1997.

65. Mair, J.; Noboa, E. Social Entrepreneurship: How Intentions to Create a Social Enterprise Get Formed; IESE Business School Working Paper Series; IESE Business School: Barcelona, Spain, 2003; Volume 503, pp. 1-29.

66. Shaw, E.; Carter, S. Social entrepreneurship. J. Small Bus. Enterp. Dev. 2007, 14, 418-434. [CrossRef]

67. Mohiuddin, M.; Parveen, R.; Ibn Rahman, M.; Mazumder, M.N.H. Entrepreneurial Motivation and Social Enterprises: An Empirical Analysis on Founders of Social Ventures in Bangladesh. Transnatl. Corp. Rev. 2013, 5, 77-92. [CrossRef]

68. Germak, A.J.; Robinson, J.A. Exploring the Motivation of Nascent Social Entrepreneurs. J. Soc. Entrep. 2013, 5, 5-21. [CrossRef]

69. Braga, J.; Proenca, T.; Ferreira, M. Motivations for social entrepreneurship-Evidences from Portugal. Tékhne 2014, $12,11-21$. [CrossRef]

70. Yitshaki, R.; Kropp, F. Motivations and Opportunity Recognition of Social Entrepreneurs. J. Small Bus. Manag. 2016, 54, 546-565. [CrossRef]

71. Sana, H.; Alkhalaf, S.; Zulfiqar, S.; Al-Rahmi, W.; Al-Adwan, A.; AlSoud, A. Upshots of Intrinsic Traits on Social Entrepreneurship Intentions among Young Business Graduates: An Investigation through Moderated-Mediation Model. Sustainability 2021, 13 , 5192. [CrossRef]

72. Biggeri, M.; Testi, E.; Ferrannini, A. A framework to understand enabling ecosystems for Social Enterprises. In Social Entrepreneurship and Social Innovation: Ecosystems for Inclusion in Europe; Routledge: London, UK, 2018. [CrossRef]

73. McCulloch, M.; Ridley-Duff, R. To profit or not to profit? That is the wrong question. In Proceedings of the 7th EMES International Research Conference on Social Enterprise, Sheffield, UK, 24-27 June 2019.

74. Testi, E.; Biggeri, M.; Colucci, D.; Doni, N.; Valori, V. Are Decision Makers in Social Enterprises More Pro-Social Than Their Peers? An Analysis of Production and Consumption Choices; Routledge: London, UK, 2018; pp. 69-95.

75. Borzaga, C.; Ianes, A. L'Economia della Solidarietaà. Storia e Prospettive della Cooperazione Sociale; Donzelli Editore: Roma, Italy, 2006. 
76. Noya, A.; Clarence, E. Entrepreneurial Activities in Europe-Social Entrepreneurship; OECD Employment Policy Papers, No. 3; OECD Publishing: Paris, France, 2013. [CrossRef]

77. Bull, M. Reconceptualising social enterprise in the UK through an appreciation of legal identities. Int. J. Entrep. Behav. Res. 2018, 24, 587-605. [CrossRef]

78. Ridley-Duff, R.; Bull, M. Understanding Social Enterprise: Theory and Practice; Sage Publications: London, UK, 2019.

79. Biggeri, M.; Ferrannini, A. Framing REI for Transformative Change Towards Sustainable Development in the European Union; DG Research and Innovation: Brussels, Belgium, 2020. 